\title{
From Bologna to Zoom: The Evolution of the University
}

\section{Glynn Custred}

Those who were students in the 1960s, and who then joined the ranks of university faculties and administrations, have seen in that short span of history a rapid flow of events which has brought substantial changes to the institution; changes which may well mark the beginning of a major turn in the history of the university. In the field of education, as in other domains, some knowledge of the past can help us better understand the present and what it might mean for the future.

The university we know today is a creation of Western Europe. It emerged near the end of the eleventh century from the cathedral school, an institution established for training the clergy, but also for the academic benefit of the sons of the nobility, and for the training of clerks and others as the need for literate men increased. The university took on a definite shape during the twelfth century, spreading throughout Europe, then to the Americas and eventually around the world. The first universities appeared in Bologna and in Paris. Bologna is recognized as the first, for it was there that teachers of the liberal arts, which comprised the curriculum of the cathedral schools, began to concentrate on the study of civil law. For purposes of commemoration, the date of its founding has been set at 1088 with the motto Alma Mater Studiorum. The university that emerged in Paris at about the same time was centered on the study of the liberal arts and theology. Those two institutions developed along similar lines, serving as models for others across Europe. Bologna and Paris are now recognized as the archetypes from which the modern university has evolved. ${ }^{1}$

1 Stefan Fisch, Geschichte der Europäischen Universität von Bologna nach Bologna (Munich: C. H. Beck, 2015).

Glynn Custred is professor emeritus of anthropology at California State University, East Bay; glynncustred@sbcglobal.net. Professor Custred is the author of A History of Anthropology as a Holistic Science (2016) and last appeared in our pages in fall of 2020 with "The Deconstruction of the Nation State." 
The word university today refers to a specific type of institution of higher learning. But it originally referred to any self-governing association with collective legal rights and with the authority to determine qualifications for entry, that is, essentially, associations organized for the benefit of specific enterprises, such as merchants and craftsmen or municipal or other administrative bodies. In the case of advanced learning they were called the universitas magistorum et scholarium, “community of teachers and students. The legal rights of those guild-like associations were guaranteed by the church, and in most cases confirmed by royal charter or by some other secular authority.

There was a great deal of linguistic diversity in medieval Europe, seen not only in the languages spoken in different countries, but also in dialect variation within countries, for there were no written standard national languages at that time, and local dialects in one country could diverge to the point of mutual unintelligibility. This, together with the great mobility of students and teachers and the uniformity of the curriculum, required some common language. Latin served that purpose; not the rigid Latin of Antiquity, which by then was no longer spoken, but by a more flexible Latin capable of expressing new ideas for a new age-a language used for reading and writing, for delivering lectures and for ordinary oral communication.

The subject of grammar, therefore, was basic to education in the Middle Ages, a discipline that along with rhetoric (how to effectively use language), and dialectic or logic (how to use language for rational thought and for logical enquiry and discourse), formed the trivium. Four more disciplines, known as the quadrivium, were also included. They were arithmetic, geometry, music, and astronomy which together with the trivium constituted the seven liberal arts; they were called "liberal" since they were independent of more specialized fields of knowledge. The quadrivium goes back to ancient Greece and to the work of Pythagoras (500 B.C) who sought the fundamental principles of the universe as revealed in regularities that could be expressed in mathematics. Music, or harmonics, entered the picture since it exhibited the same regularities as did numbers and their relationship to one another. The quadrivium was thus an introduction to how the broader world was viewed by scholars of the time. With mastery of the fundamentals in the liberal arts, the student was qualified for further study in one of the other fields of the medieval university: medicine, the law, and-the "queen of sciences"-theology. 
Hastings Rashdall, in his description of the medieval university, says that one of the hallmarks of the Middle Ages was its development of institutions. This is clearly seen in the university, which, he says, is more imperishable than the cathedrals of that time, for the university of today is essentially a medieval institution. Some of this, says Rashdall, is natural, but other aspects are not necessary for proper training, and can and have been achieved in other ways. Yet there is a direct continuity from the medieval university to the present as seen in the university's administrative offices and titles, its organization into faculties with different specialties, along with a general education requisite (even in the name "liberal arts"), and in its customs, ceremonies, degrees of achievement (baccalaureate, master's, and the doctorate).

The medieval university was firmly founded on doctrine, yet within that framework it became a center of intellectual activity and innovation. Scholarship at that time, unlike today, was not designed to push back the frontiers of knowledge, but rather to extend and deepen knowledge within the framework established by Christian doctrine. This was done by resolving theological contradictions within Christian theology, and by harmonizing the work of the early church fathers with ancient philosophy, primarily with Aristotelian logic and science. This they did by means of rigorous conceptual analysis. From those efforts emerged scholasticism and the elaboration of logic, as seen in the work of Peter Abelard, Albertus Magnus, Duns Scotus, William of Ockham, Thomas Aquinas, and others whose work has helped shape that branch of knowledge as it is used today. Universities in the Early Modern Period (c. 1500 and into the eighteenth century) were also where some of the earliest innovators of science appeared. In that respect one can see today in the university of Padua (established in 1222 or earlier), the lectern from which Galileo lectured, and the amphitheater where dissections were performed in the research and teaching of anatomy.

Although maintaining its essential structure, the university has also been shaped over time by major historic events. One of them was the Reformation of the sixteenth century which resulted in the founding of Protestant universities. Those institutions were not detached from doctrine, but rather from the official authority of the Catholic Church and its version of theology. The first of those institutions was Phillips University in Marburg founded in 1527. Others followed, and much later Catholic universities of high repute were established. 
Reforms in line with changing times were brought to higher education by Wilhelm von Humboldt with the founding of the university in Berlin in 1808 . The goal was to produce a broadly educated middle class from which, among other benefits, better prepared and more widely informed members of the bureaucracy could be recruited in the interest of the greater efficiency of the state. This was done by combining study with research, especially research in the sciences, which by that time were rapidly producing ever wider ranges of knowledge and application, a holistic approach that resulted in greater achievements in science and scholarship that became the basis for the enormous international prestige of the German university in the nineteenth century.

The university outside Europe was the result of the spread of European cultural patterns that began in the early colonial expansion of Western European countries. The first of those institutions was on the island of Santo Domingo in the Caribbean, founded in 1538, and the first on the mainland of the Americas were San Marcos University in Lima, Peru and the University in Mexico City founded in 1551. Structurally those institutions were similar to the one in Salamanca, the oldest university in Spain, founded in 1134, and were in line with the ecclesiastical and the missionary monastic orders which were active in the Spanish possessions. The curriculum was the same as in Europe except for new faculties for the teaching of and research into the most widely used indigenous languages of the time, Quechua in the Andes and Nahuatl in Mexico.

Most colleges in the British colonies were established by religious institutions on the model of Oxford (established in 1096), Cambridge (1209) and the Scottish universities (St. Andrews 1417, Glasgow 1451, Aberdeen 1495, and Edinburgh 1581). The first in the colonies was Harvard College established in 1636, just sixteen years after the arrival of the Mayflower. Their mission statement says that the college would provide ministers and others with a good education and would "advance learning and perpetuate it to posterity" by teaching the liberal arts which included Latin, Greek, and Hebrew. William and Mary College was founded in Virginia in 1693 with a divinity school, a faculty for the training of lawyers and the educating the sons of merchants and planters, for in those days a knowledge of the classics was a sign of good breeding. As the newly formed United States moved West, academies and seminaries were founded which formed the nuclei for later institutions of higher education. In 1862 and again in 1890 the Morrill Acts allowed states to sell public land 
to finance institutions of higher education, known as land grant colleges, eventually resulting in the establishment of state universities, although three private universities were also funded in that way, MIT, Cornell, and Tuskegee.

Those institutions were focused on agriculture, science, and engineering in response to the industrial revolution but they also provided training in law and medicine as well as a broad general education, for the consensus at the time was that an educated citizenry was necessary for the proper functioning of a democratic society. During the nineteenth century serious scholars began to travel to Germany seeking the benefits of the German university. Eventually the Humboldtian ideal was adopted by the universities of the United States with Johns-Hopkins in 1874 integrating teaching with research and adopting the concept of the graduate school from the example of the university in Heidelberg (founded in 1386). In the 1940s a number of post-secondary institutions were established known as junior or community colleges, where the first two years of the general curriculum were taught as well as a number of useful skills. College enrollment was greatly expanded after World War II with the GI Bill. A college degree had by then become a sign of middle-class status, and its attainment by those who were the first in their family to attend college was a laudable sign of upward social mobility, often recognized at graduation ceremonies. But the major benefit of a college degree, and why it was sought even at sometimes great expense, was that it permitted entry into a well-paying career.

This system of higher education for the masses, as well as for the select few, is seen around the country, but is perhaps best represented by California's three-tiered system of public higher education, which has been described as a pyramid. The base of the pyramid is a network of community colleges in close proximity, with easier student access and lower cost, and with access to the other tiers in the system. The next level is comprised of the campuses of the California State University system, which offer only the bachelor and the master's degrees. These colleges are more selective in their admission policies and place less emphasis on research. The top tier consists of the campuses of the University of California, which are more selective and which stress research. They also include law and medical schools along with the Ph.D. degree in other fields. This three-tiered system aims for the highest inclusion possible, and has been called a model of public higher education for the modern world.

A characteristic of the university is youth, for the majority of the members of the academic community are students, exhibiting the exuberance, 
enthusiasm, and sometimes recklessness of their age group. But among them are also the dedicated and serious minded who are engaged in the enterprise of scholarship and potentially ready to engage in other idealistic pursuits. The latter is seen in the late Middle Ages in the description of the clerk (graduate student of philosophy or theology) of Oxenford (modern Oxford) in Geoffrey Chaucer's Canterbury Tales. He is described as wearing threadbare clothes over his emaciated frame, preferring books to good food, and who would gladly learn and gladly teach. On the other end of the spectrum is the leisure life of many students of the time (and indeed of any time) as seen most strikingly in the Goliardic songs composed by vagabond scholars who praised drinking and merry making, reflecting the youthful collegiality of the medieval university, and indicating the way many spent their free time, often in taverns gambling, drinking, and singing as heard in the thirteenth century song In Taberna

In taberna quando sumus

Non curamus quid sit humus

Sed ut ludum properamus

When we are in the tavern

We do not think how we will turn to dust

But hurry up to gamble...2

The guild-like collegial structure of the medieval university and the rambunctious nature of the students sometimes led to clashes with the people and the authorities of the towns in which they were located, even to the point of street brawls. There were also sometimes disputes between the university as a whole and the community, giving rise to the expression "town and gown.” Today the collegiality of student days, especially among members of fraternities, often

2 John Addington Symonds, Wine, Women and Song (New York: Cooper Square Publisher, 1966). 
lingers into later life with loyalty to the alma mater, which accounts for many of the donations that enhance its effectiveness.

This youthful exuberance and a sense of mission converged during the 1840s against the prevailing rule of monarchs and in support of liberalism and democracy, a time of revolutionary fervor in Europe, when many students and graduates felt a sense of liberal responsibility and were prominent figures on the barricades. In German lands they were well represented in a move toward national unification. Students were also represented among the ranks of the National Socialist German Workers' Party (Nazis) in the tumultuous days of the Weimar Republic of the 1920s. The National Socialist movement was a dominant force among students long before its party took power in 1933. The reason was the suspicion on the part of many students that the Weimar authorities were not loyal to the national ideal, while the National Socialists, as they saw it, defended that ideal. Many student fraternities regularly protested against professors who they viewed as not supporting traditional German values as defined by Nazi ideology.

There were only a few in the 1920s who recognized the threat this movement posed for the traditional German university and for the academic community. As historian Michael Steven Steinberg observes, National Socialism was antiintellectual, denying the possibility of objectivity and the value of freedom to think beyond narrowly imposed ideological constraints; a movement that praised activism and scorned contemplation. "The ideal of intellectual liberty which had been cherished by generations of German scholars," writes Steinberg, "was mocked by the Nazis as a foreign importation." ${ }^{3}$ In the long run, much of the success of the Nazis with students can be attributed to the Nazis' ability to excite large numbers of students about the political struggle taking place around them.

But it was not just the students who backed the new regime. Even before the National Socialists came to power there were notable scholars who were committed to the ideology, or once the party came to power, went along with it. The most prominent and committed example was the philosopher Martin Heidegger who became rector of the University of Freiburg after the Nazis assumed power, and who, after the war, never renounced his membership in the party. Others went along with it for reasons of self-promotion or simply to

3 Michael Steven Steinberg, Sabers and Brownshirts: German Students' Path to National Socialism 1918-1935, (Chicago: University of Chicago Press, 1977). 
be left alone. Formal mechanisms were also put in place to instruct university appointees and faculty on the proper ideological positions from which they were not to deviate.

The radical transformation in the American university we see today began with a gradual leftward drift in the 1940s, for Marxism seems to have a special fascination for many intellectuals. ${ }^{4}$ This was seen in the reluctance of many of them to criticize too harshly the actions of Communist governments, and to praise those that had yet to exercise full power. The Marxist influence was also seen in some serious and useful scholarly work such as that of Eric Hobsbawm and Eugene Genovese. But Marxism is adaptable, shifting from the classic formulation of class conflict in the nineteenth century to the more topical current issues of race and gender in what has been called Neo-Marxism, with its own form of Newspeak appropriate to the prescribed ideological formulation. This movement followed the lead of Antonio Gramsci (although few are aware of this today), in which he said that intellectuals must take the lead, infiltrating cultural institutions to change society from the inside, a position endorsed by the Frankfurt school of Marxism and succinctly expressed in the 1960s by student radical Rudi Dutschke in the slogan, "the long march through the institutions to capture the culture."

That goal has finally been reached in academia, for what had once been a free marketplace of ideas where rational debate is encouraged and different perspectives considered, is now an institution of political indoctrination where Western civilization is denigrated and where a narrow, ideologically channeled way of feeling, believing, and thinking is preached. In a real sense this is a return to the doctrine-based era in the history of the university; only unlike then, there is no latitude today for innovation within the doctrinal framework. Instead, like their counterparts in Germany in the 1930s, universities today require ideological uniformity, much of it enforced informally through shunning and public denigration, although it is more and more taking a formal direction.

University administrations have also been brought in line as seen in sometimes embarrassing capitulations to political correctness. In this respect Frederick Hess, the director of education studies at the American Enterprise Institute, says, “The American University today has, bizarrely, become a place

4 Paul Hollander, From Benito Mussolini to Hugo Chavez (Cambridge: Cambridge University Press, 2017); Paul Johnson, Intellectuals (New York: Harper and Row Publishers, Inc., 1988), vii-xii. 
dominated by anger, fear, and self-loathing, all wrapped in an unloving cloak of self-righteousness." ${ }^{5}$

One of numerous examples is Princeton University’s president Christopher Eisgruber who recently wrote about what he describes as "racism and the damage it has done to people of color . . . at Princeton," inasmuch as "racist assumptions" are "imbedded in structures of the university itself." This is either the expression of a committed true believer, or the words of a mediocre administrator who fears the damage the proponents of radical transformation might do to him and the institution if he refuses to parrot the politically correct mantras.

But despite their victory, it is becoming evident that the institution which Neo-Marxists and their host of followers have captured, might have reached its limits, not only because of the way it has undermined learning and free speech, but also because of other factors that have been building in recent times, for today's students are increasingly abandoning traditional institutions of higher education as seen in the steady decline in enrollment which is down more than two million since its peak in 2010. Also, many students today do not see much value in accumulating a massive debt simply to receive a general education degree, especially when a less costly certificate in a specific subject or set of skills can provide similar career credentials. Under these conditions what were once prestigious institutions may well shrink in prominence and importance as time goes by.

Added to all this is the reaction of institutions of higher education to the novel corona virus pandemic by shutting down the institutions and substituting online courses without substantially reducing the price of tuition. John Ellis, emeritus from the University of California, Santa Cruz has raised a number of possibilities that may result from large-scale, online instruction. One is the sharp increase in transparency it offers parents, who can easily observe what is being taught to their kids. In the field of history, for example, parents are now able to see for themselves, not just hear about, how such revisionists as Howard Zinn and the 1619 Project have distorted American history.

With teachers able to reach any audience online, Ellis sees the possibility that private companies might poach the most inspired among them, developing programs along the lines of the Hillsdale College program or TED Talks.

5 Frederick Hess, "Don't Fix Colleges: Build Them," National Review (October, 2020), 38-40. 
Regional centers for testing might also be established for competency-based programs, which grant certificates for proven knowledge in place of a diploma, at a fraction of the cost, much like licensing boards in the trades and crafts, and the bar exam for the practice of law. Together with the leftward, antiintellectual tilt of the university, these developments may eventually outweigh the perceived value of a diploma.

Yes, the collegiality that fosters teamwork, cooperation, questioning, discussing, debating, and thinking through how to defend or attack a position from a rational point of view, is lost with online instruction. But Rashdall noted long ago universities are not the only way to achieve such goals. ${ }^{6}$ Helping scientists test and experiment in the laboratory, or helping the scholar in the archives examining some early document to reveal the reality of the life and times of those who produced it; seeing how it is done and later passing that knowledge and those skills on to others is already a part of university and post-doctoral training. This can be experienced outside the university, for apprenticeship with its own recognition of attainment and official systems of authoritative licensing predates even the university.

There is still the attraction of the Halls of Ivy, the ceremonies at the rite of passage of graduation, the collegiality of campus life, and a fond attachment to the alma mater. Universities can still provide these benefits, providing faculty and administration recognize this appeal and act on it. It is not clear at this time that they will, for far too many of them are so enmeshed in doctrine that they do not see the challenges higher education faces. In some ways this is analogous to the 1920s in Germany when only a few recognized the harmful effects that the adoption of an ideology in place of liberal higher learning would have on the institution and on the community of scholars and students. Until there is such a recognition, those forces which shape institutions will continue playing a major role in the long history of the university, this time to its detriment.

6 Hastings Rashdall, The Universities of Europe in the Middle Ages. New Edition in three volumes by F. M. Powicke and A.B. Emden (Oxford: Oxford University Press, 1936 [1895]). 